\title{
\begin{tabular}{l|l|l} 
Jurnal Eksplorasi Akuntansi & $\begin{array}{l}\text { e-ISSN : 2656-3649 (Online) } \\
\text { Vol. 3, No 1, Februari 2021, Hal 170-187 }\end{array}$
\end{tabular}
}

\section{Pengaruh Dana Alokasi Umum (DAU), Pendapatan Asli Daerah (PAD), dan Dana Bagi Hasil (DBH) Terhadap Belanja Modal dengan Sisa Lebih Pembiayaan Anggaran (SILPA) sebagai Variabel Pemoderasi pada Pemerintah Provinsi se-Indonesia Periode 2015-2019}

\author{
Syofyan Yuliantoni' ${ }^{1}$, Fefri Indra Arza, SE., M.Sc., $\mathbf{A k}^{2}$ \\ 1,2Jurusan Akuntansi Fakultas Ekonomi Universitas Negeri Padang \\ *Korespondensi: syofyanyuliantoni98@gmail.com
}

\begin{abstract}
This study aims to determine the effect of General Allocation Fund (DAU), Regional Original Income (PAD), and Revenue Sharing Fund (DBH) on Capital Expenditures with Excess Budget Financing (SILPA) as a Moderating Variable in Provincial Governments throughout Indonesia 2015-2019. The data use in this study is the report on the realization of APBD for the 2015-2019 fiscal year which is available on the DJPK website. The population and sample in this study ara all provincial governments in Indonesia consisting of 34 provinces from 2015-2019 with a total of 170 data. Hypothesis testing in this study uses the Moderated Regression Analysis (MRA) test. The result showed that DAU had a significant effect on capital spending, PAD and DBH had no effect on capital spending, SILPA does not moderate $D A U, P A D$, and $D B H$ on capital expenditures.
\end{abstract}

Keywords: General Allocation Funds, Local Own Income, Revenue Sharing Funds, Capital Expenditures, Remaining Budget Financing

\section{How to cite}

Yuliantoni, S., \& Arza, F. I. (2021). Pengaruh Dana Alokasi Umum (DAU), Pendapatan Asli Daerah (PAD), dan Dana Bagi Hasil (DBH) Terhadap Belanja Modal dengan Sisa Lebih Pembiayaan Anggaran (SILPA) sebagai Variabel Pemoderasi pada Pemerintah Provinsi se-Indonesia Periode 2015-2019. Jurnal Eksplorasi Akuntansi. 3(1). $170-187$.

\section{PENDAHULUAN}

Sejak awal tahun 1997 Indonesia mengalami krisis ekonomi yang membuat perekonomian terpuruk sehingga mendorong pemerintah untuk membagi wewenang pengelolaan keuangan kepada daerah. Krisis ekonomi yang terjadi merupakan cikal bakal terjadinya reformasi di bidang pemerintahan daerah dan pengelolaan keuangan yang dimulai sejak tahun 1999. Pelaksanaan reformasi tersebut sejalan dengan ditetapkannya UU No. 22 Tahun 1999 tentang Pemerintahan Daerah kemudian di revisi menjadi UU No. 32 Tahun 2004, dan UU No. 25 Tahun 1999 tentang Perimbangan Keuangan Pusat dan Daerah kemudian di revisi menjadi UU No. 33 Tahun 2004.

Undang-Undang Nomor 32 Tahun 2004 memberikan kewenangan yang luas bagi pemerintah daerah untuk mengatur dan mengurus daerahnya sendiri, hal ini sejalan dengan kebijakan otonomi daerah. Kebijakan otonomi daerah mampu menciptakan kemandirian bagi 
daerah untuk membangun daerah dengan menggali potensi dari sumber-sumber keuangan daerah yang dimiliki dan dapat mengurangi ketergantungan terhadap pemerintahan pusat. UU No. 33 Tahun 2004 pasal 10 tentang perimbangan keuangan antara pemerintahan pusat dan pemerintahan daerah menyatakan bahwa sumber-sumber pembiayaan untuk pembangunan daerah bersumber dari Pendapatan Asli Daerah (PAD), dan Dana Perimbangan yang diperoleh dari Pemerintahan Pusat. Dana Perimbangan terdiri dari Dana Alokasi Umum (DAU), Dana Bagi Hasil (DBH), dan Dana Alokasi Khusus (DAK), serta sumber lain dari pembiayaan dapat berupa pinjaman daerah.

Upaya peningkatan kemandirian dalam pembangunan daerah sekaligus meningkatkan pendapatan daerah, daerah otonom yang baru memiliki berbagai tantangan dan kendala yaitu ketersediaan sumber daya di daerah yang terbatas. Dengan demikian diperlukan kebijakan dan strategi yang tepat dan mampu mencapai kriteria-kriteria prioritas pembangunan salah satunya peningkatan investasi disuatu daerah. Permasalahan yang sering dihadapi oleh pemerintah daerah dalam organisasi sektor publik yaitu mengenai pengalokasian anggaran. Pengalokasian anggaran merupakan jumlah alokasi dana untuk masing-masing program. Sumber daya yang terbatas, mengakibatkan pemerintah daerah harus dapat mengalokasikan penerimaan yang diperoleh untuk belanja daerah yang bersifat produktif. Belanja daerah merupakan estimasi beban pengeluaran daerah yang dialokasikan secara adil dan merata agar relatif dapat dinikmati oleh seluruh kelompok masyarakat tanpa diskriminasi, terutama dalam pemberian pelayanan umum.

Selama ini, pemerintah daerah lebih banyak menggunakan pendapatan daerah untuk kepentingan belanja operasi daripada belanja modal (Kawedar, 2008). Belanja modal merupakan belanja dari pemerintah daerah yang mana manfaatnya lebih dari satu tahun anggaran dan akan menambah aset ataupun kekayaan daerah yang selanjutnya akan menambah belanja yang bersifat rutin seperti biaya pemeliharaan pada kelompok belanja administrasi umum (Halim, 2012). Belanja dapat dikategorikan kedalam belanja modal apabila: 1) pengeluaran tersebut akan mengakibatkan adanya perolehan aset tetap/ aset lainnya yang menambah masa umur, manfaat dan kapasitas; 2) pengeluaran tersebut melebihi dari batasan minimum kapitalisasi aset atau lainnya yang telah ditetapkan pemerintah; 3) perolehan aset tetap tersebut diniatkan bukan untuk dijual.

Alokasi belanja modal di dasarkan pada kebutuhan daerah akan sarana dan prasarana, baik untuk kelancaran pelaksanaan tugas pemerintahan maupun untuk fasilitas pubik, dimana selama ini belanja daerah lebih banyak digunakan untuk belanja rutin yang relatif kurang produktif (Rendy, 2018). Pemamfaatan belanja hendaknya dialokasikan untuk hal hal-hal yang produktif seperti untuk melakukan aktivitas pembangunan (Wimpi, 2016). Sejak tahun 2015 sampai 2019 masih banyak daerah-daerah dimana perolehan belanja modalnya masih rendah. Pada tahun 2015 persentase belanja modal secara keseluruhan di Indonesia berjumlah 18,15\% dari total belanja daerah, sedangkan tahun 2016 turun menjadi 16,94\% dan tahun 2017 mengalami kenaikan 0,02\% atau sekitar 16,96\%. Tahun 2018 dan 2019 secara berurutan persentase belanja modal di Indonesia mengalami penurunan kembali menjadi $15,78 \%$ dan $14,19 \%$.

Sejak tahun 2015-2019 di Indonesia secara agregat ada 6 (enam) provinsi dimana persentase realisasi belanja modal dari total belanja daerahnya mengalami penurunan dari tahun ke tahun, yaitu Jawa Timur, Papua, Kalimantan Timur, Nusa Tenggara Barat, Gorontalo dan Kalimantan Utara. Provinsi Jawa Timur dari tahun 2015 sampai 2019 secara berurutan persentase realisasi belanja modal dari total belanja daerahnya yaitu $9,8 \%, 9,0 \%$, $58,7 \%, 9,3 \%$, dan 8,2\%. Pada Provinsi Papua juga mengalami penurunan dimana tahun 2015 berjumlah 23,1\% atau sekitar Rp. 2.865.461.762.743 sedangkan tahun 2016 turun menjadi Rp. 2.490.333.441.810, atau sekitar 20,8\% dan tahun selanjutnya dari tahun 2017 sampai 2019 secara berurutan turun sekitar $17,5 \%, 14,5 \%$, dan $16,7 \%$. Salah satu faktor yang menyebakan 
turunnya realisasi belanja modal adalah ganti rugi lahan yang belum terselesaikan di Kementrian PUPR maupun Kementrian Perhubungan, dan gangguan keamanan juga menghambat pelaksanaan pekerjaan pemerintah (www.katadata.co.id).

Berbeda dengan provinsi Kalimantan Timur yang juga mengalami penurunan presentase realisasi belanja modal dari total belanja daerahnya secara berurutan dari tahun 2015 sampai tahun 2019 yaitu 19,7\%, 20,7\%,11,4\%, 19,6\%, dan 10,6\%, hal ini disebabkan oleh pengurangan terhadap belanja peralatan dan mesin seperti belanja komputer, mesin dan lainnya, hal tersebut dilakukan oleh pemerintah daerah Kalimantan Timur dengan tujuan efisiensi penggunaan anggaran (www.akurat.co). Untuk Provinsi Nusa Tenggara Barat penurunan presentase realisasi belanja modal secara berurutan dari tahun 2015-2019 yakni berjumlah 24,8\%, 18,5\%, 21,9\%, 17,0\%, 13,0\%. Penurunan pada Provinsi Gorontalo secara berurutan dari tahun 2015-2019 yaitu 24,5\%, 18,6\%, 14,7\%, 15,3\%, 14,4\% hal ini disebabkan karena selain proses pembebasan lahan yang berlarut-larut yang menyebabkan turunnya realisasi belanja modal, juga disebabkan oleh DIPA (Daftar Isian Pelaksanaan Anggaran) yang terlambat diterima (www.hulondalo.id). Penurunan di Provinsi Kalimantan Utara secara berurutan dari tahun 2015-2019 yakni 35,3\%, 31,2\%, 26,7\%, 27,1\%, 23,5\%. Hal ini menyiratkan bahwa masih banyak program pemerintah yang belum teralisasi dengan baik dari tahun ketahun.

Farah (2011) mengatakan desentralisasi fiskal memberikan kewenangan yang besar kepada daerah untuk menggali potensi yang dimiliki sebagai sumber pendapatan daerah untuk membiayai pengeluaran daerah dalam rangka pelayanan publik. Sumber pendapatan daerah sesuai dengan UU No. 32 Tahun 2004, yaitu hasil pajak daerah, hasil retribusi, hasil pengelolaan kekayaan daerah yang dipisahkan dan lain-lain PAD yang sah. Peningkatan PAD tidak diikuti dengan kenaikan anggaran belanja modal yang signifikan hal ini disebabkan oleh PAD banyak digunakan untuk membiayai belanja lainnya dan juga di berbagai daerah perolehan PAD masih cukup rendah.

Perbedaan dalam kemampuan keuangan terutama penerimaan pendapatan daerah akan menimbulkan ketimpangan fiskal antara suatu daerah dengan daerah lainnya, oleh karena itu untuk mengatasi ketimpangan fiskal pemerintahan pusat mengalokasikan dana yang bersumber dari APBN untuk mendanai kebutuhan daerah dalam pelaksanaan desentralisasi (Rendy, 2018). Dana perimbangan meliputi Dana Alokasi Umum (DAU) dan Dana Bagi Hasil (DBH). Dana perimbangan digunakan untuk membantu daerah dalam mendanai kegiatan-kegiatan daerah dan juga untuk mengurangi kesenjangan pendanaan pada pemerintahan antar daerah.

Beragamnya hasil penelitian terdahulu kemungkinan diakibatkan oleh adanya variabel pemoderasi. Pengaruh dari variabel pemoderasi dapat memperkuat atau memperlemah hubungan diantara variabel independen dengan variabel dependen. Penelitian ini menggunakan SILPA sebagai variabel pemoderasi. Berdasarkan PP No. 71 Tahun 2010 tentang Standar Akuntansi Pemerintah, menyatakan bahwa SILPA merupakan selisih lebih antara realisasi pendapatan-LRA dan belanja, serta penerimaan dan pengeluaran pembiayaan dalam APBN/APBD selama satu (1) periode pelaporan. Selain Pendapatan Asli Daerah, daerah juga bisa memanfaatkan SILPA tahun sebelumnya untuk mendanai berbagai pelaksanaan kegiatan lanjutan atas beban belanja langsung dan mendanai kewajiban lainnya yang sampai dengan ahir tahun anggaran belum terselesaikan (Widya, 2018). Jumlah SILPA yang cenderung besar menunjukan lemahnya eksekutif di bidang perencanaan dan pengelolaan dana.

Sejak tahun 2015 sampai tahun 2018, DKI Jakarta adalah salah satu daerah yang memiliki jumlah SILPA yang tinggi di bandingkan dengan daerah lain. Tepatnya pada tahun 2018, jumlah SILPA di DKI Jakarta sekitar Rp.9.755.149.083.281, hal ini disebabkan kurang optimalnya pemerintahan daerah dalam penyerapan anggaran APBD (www.antaranews.com). 
Hasil penelitian Fiona (2013) menunjukan bahwa pendapatan asli daerah dan dana alokasi umum berpengaruh positif terhadap belanja modal. Rudi (2017) menjelaskan bahwa pendapatan asli daerah, dana bagi hasil, dan dana alokasi umum berpengaruh secara signifikan terhadap belanja modal. Wimpi (2017) menyatakan bahwa pendapatan asli daerah dan dana alokasi umum berpengaruh signifikan terhadap belanja modal. Namun dari beberapa peneliti terdapat hasil yang tidak konsisten, seperti Farah (2011), Wandira (2013), dan Widya (2018) menunjukan bahwa pendapatan asli daerah tidak memiliki pengaruh yang signifikan terhadap belanja modal, sedangkan dana alokasi umum memiliki pengaruh yang signifikan terhadap belanja modal. Made (2018) dana alokasi umum tidak berpengaruh terhadap aloaksi belanja modal. Rendy (2018) juga menyatakan bahwa pendapatan asli daerah tidak mempengaruhi secara signifikan terhadap belanja modal sedangkan dana alokasi umum memiliki pengaruh yang signifikan terhadap belanja modal.

\section{REVIEW LITERATUR DAN HIPOTESIS \\ Teori Keagenan (Agency Theory)}

Penelitian ini menggunakan grand theory yaitu teori agency. Pada dasarnya teori agensi menjelaskan terdapat hubungan yang timbul karena adanya kontrak antara dua belah pihak yaitu rakyat (sebagai principal) yang memberikan tanggungjawabnya kepada pemerintah (sebagai agent) untuk menyediakan jasa atas kepentingan rakyat (Jensen dan Meckling, 1976). Dalam teori keagenan pihak agent dan principal terdapat perbedaan kepentingan, dimana agent tidak selalu melakukan tindakan terbaik bagi kepentingan principal. (Bangun 2009 dalam Yovita 2011) menjelaskan bahwa teori keagenan adalah cabang dari game theory yang mempelajari suatu model kontraktual dimana akan mendorong agent untuk bertindak bagi principal saat kepentingan agent bisa saja bertentangan dengan kepentingan principal.

Pihak rakyat (principal) mendelegasikan pertanggungjawabannya atas pengambilan keputusan kepada agent, yang mana wewenang dan tanggungjawab agent dan principal diatur berdasarkan kontrak kerja atas persetujuan bersama. Pihak agent bertanggungjawab dalam memaksimalkan keuntungan bagi principal, akan tetapi agent juga berkepentingan untuk meningkatkan kesejahteraan sendiri, sehingga dalam kenyataannya wewenang yang diberikan principal kepada agent sering terjadi masalah karena tujuan principal berbenturan dengan tujuan pribadi agent. Perbedaan informasi yang dimiliki oleh keduanya menyebabkan terjadinya asimetri informasi (information asymmetry) dan konflik kepentingan (conflict of interest). Menurut Jensen dalam bukunya ada dua macam masalah agensi yaitu : Moral Hazard, dan Adverse Selection.

\section{Keuangan Daerah}

Berdasarkan PP No. 12 Tahun 2019 tentang pengelolaan keuangan daerah menyatakan bahwa keuangan daerah merupakan semua hak dan kewajiban daerah dalam rangka penyelenggaraan pemerintahan daerah yang dapat dinilai dengan uang dan segala bentuk kekayaan yang dapat dijadikan milik daerah berhubung dengan hak dan kewajiban daerah tersebut. Ruang lingkup Keuangan Daerah yaitu : Hak bagi daerah untuk memungut pajak daerah dan retribusi daerah serta melakukan pinjaman; Kewajiban daerah dalam menyelenggarakan urusan pemerintahan daerah serta membayar tagihan pihak ketiga; Penerimaan daerah; Pengeluaran daerah; Kekayaan daerah yang dikelola sendiri atau dikelola oleh pihak lain baik berupa uang, surat berharga, piutang, barang, serta hak lain yang dapat dinilai dengan uang termasuk kekayaan daerah yang dipisahkan; Kekayaan pihak lain dikuasai oleh pemerintah daerah dalam rangka penyelnggaraan tugas pemerintahan daerah dan/atau kepentingan umum. 


\section{Anggaran Pendapatan dan Belanja Daerah (APBD)}

Anggaran Pendapatan dan Belanja Daerah (APBD) di atur berdasarkan UU Nomor 17 Tahun 2003 Tentang Keuangan Negara. Berdasarkan UU Nomor 17 Tahun 2003 Pasal 16 Ayat 1 APBD (Anggaran Pendapatan dan Belanja Daerah) merupakan bentuk wujud pengelolaan keuangan daerah yang ditetapkan setiap tahun dengan Peraturan Daerah. APBD terdiri dari anggaran pendapatan, anggaran belanja, dan pembiayaan. Dengan adanya pos pembiayaan sehingga akan memperlihatkan APBD semakin informatif yang artinya memisahkan antara pinjaman dari pendapatan daerah. Penyusunan rancangan APBD sebagaimana dimaksud dalam ayat (1) berpedoman terhadap rencana kerja Pemerintah Daerah dalam rangka tercapainya tujuan suatu negara.

\section{Belanja Modal}

Dalam upaya memenuhi kewajiban daerah, belanja daerah akan diprioritaskan untuk melindungi dan meningkatkan kualitas kehidupan masyarakat. Upaya tersebut dapat diwujudkan dalam bentuk peningkatan pelayanan dasar, pendidikan, penyediaan fasilitas pelayanan kesehatan, fasilitas sosial dan fasilitas umum yang layak, serta mengembangkan sistem jaminan sosial dengan cara mempertimbangakan analisis standar belanja, standar harga, tolak ukur kinerja, dan standar pelayanan minimal yang ditetapkan sesuai dengan peraturan UU No. 32 Tahun 2004.

Belanja modal merupakan belanja dari pemerintah daerah yang mana manfaatnya lebih dari satu (1) tahun anggaran dan akan menambah aset ataupun kekayaan daerah serta selanjutnya akan menambah belanja yang bersifat rutin seperti biaya pemeliharaan pada kelompok belanja administrasi umum (Halim, 2012). Menurut PP No. 12 Tahun 2019 tentang pengelolaan keuangan daerah menyatakan bahwa belanja modal merupakan bentuk pengeluaran anggaran untuk perolehan aset tetap dan aset lainnya yang memberi manfaat melebihi 1 (satu) periode akuntansi. Sesuai dengan PP No. 12 Tahun 2019 pasal 65 tentang Pengelolaan Keuangan Daerah, belanja modal meliputi: belanja tanah, belanja peralatan dan mesin, belanja bangunan dan gedung, belanja jalan, irigrasi, dan jaringan, belanja aset tetap lainnya, dan belanja aset lainnya.

\section{Dana Alokasi Umum (DAU)}

Berdasarkan UU No. 33 Tahun 2004 tentang perimbangan keuangan antara pemerintah pusat dan pemerintah daerah menyatakan Dana Alokasi Umum, selanjutnya disebut DAU adalah dana yang berasal dari pendapatan APBN, dialokasikan dengan maksud pemerataan kemampuan keuangan antar-Daerah yang digunakan untuk mendanai kebutuhan Daerah dalam rangka pelaksanaan desentralisasi. Tujuan daripada Dana Alokasi Umum yaitu untuk pemerataan kemampuan keuangan antar daerah berdasarkan penerapan formula yang mempertimbangkan kebutuhan dan potensi daerah. Dana Alokasi Umum suatu daerah ditentukan berdasarkan besar kecilnya celah fiskal (fiscal gap) suatu daerah, yang merupakan selisih antara kebutuhan daerah (fiscal need) dan potensi daerah (fiscal capacity).

Berdasarkan PP No. 55 Tahun 2005 pasal 37 tentang dana perimbangan, ada beberapa ketentuan perhitungan Dana Alokasi Umum yaitu: DAU dialokasikan untuk provinsi dan kabupaten/kota; Jumlah keselururhan Dana Alokasi Umum ditetapkan sekurang-kurangnya 26\%(dua puluh enam persen) dari Pendapatan Dalam Negeri Neto; Proporsi DAU antara provinsi dengan kabupaten/kota dihitung berdasarkan perbandingan antara bobot urusan pemerintahan yang menjadi kewenangan provinsi dan kabupaten/kota; Penentuan proporsi sebagaimana dimaksud pada ayat (3) belum dapat dihitung secara kuantitatif, proporsi DAU antara provinsi dan kabupaten/kota ditetapkan dengan imbangan 10\%(sepuluh persen) dan 90\%(sembilan pulih persen); Jumlah keseluruhan DAU sebagaimana dimaksud pada ayat (2) ditetapkan dalam APBN. 


\section{Pendapatan Asli Daearah (PAD)}

Berdasarkan UU No. 33 Tahun 2004 tentang perimbangan keuangan antara pemerintah pusat dan pemerintah daerah menjelaskan bahwa pendapatan asli daerah, selanjutnya disebut PAD merupakan pendapatan yang diperoleh daerah dipungut berdasarkan peraturan daerah sesuai dengan peraturan perundang-undangan yang berlaku. Pendapatan Asli Daerah (PAD) adalah seluruh penerimaan daerah yang berasal dari sumber ekonomi asli daerah. Pendapatan Asli Daerah dapat dikelompokan menjadi: pajak daerah, retribusi daerah, hasil pengelolaan kekayaan milik daerah yang dipisahkan, dan lain-lain pendapatan asli daerah yang sah (Halim, 2012). Berdasarkan UU No. 33 Tahun 2004 pasal 6, membagi beberapa sumber dari PAD yaitu: Pajak Daerah, Retribusi daerah, Hasil Pengelolaan Kekayaan Daerah Yang Dipisahkan, dan Lain-Lain Pendapatan Asli Daerah Yang Sah.

\section{Dana Bagi Hasil (DBH)}

UU No. 33 Tahun 2004 menyatakan dana bagi hasil (DBH) merupakan dana yng berasal dari pendapatan APBN dan dialokasikan kepada daerah berdasarkan angka persentase yang digunakan untuk mendanai kebutuhan daerah dalam rangka pelaksanaan desentralisasi. Sumber DBH yaitu DBH bersumber dari pajak dan sumber daya alam, DBH yang bersumber dari pajak sebagaimana dimaksud pada ayat 1 terdiri atas:Pajak Bumi dan Bangunan (PBB); Bea Perolehan Hak atas Tanah dan Bangunan (BPHTB); Pajak Penghasilan (PPh) Pasal 25 dan Pasal 29 Wajib Pajak Orang Pribadi Dalam Negeri dan PPh Pasal 21, dan DBH yang bersumber dari sumber daya alam sebagaimana dimaksud pada ayat 1 berasal dari: Kehutanan; Pertambangan umum; Perikanan; Pertambangan minyak bumi; Pertambangan gas bumi; Pertambangan panas bumi (UU No. 33 Tahun 2004).

\section{Sisa Lebih Pembiayaan Anggaran (SILPA)}

Berdasarkan PP No. 71 Tahun 2010 tentang Standar Akuntansi Pemerintah, menyatakan bahwa Sisa Lebih Pembiayaan Anggaran (SILPA) merupakan selisih lebih antara realisasi pendapatan-LRA dan belanja, serta penerimaan dan pengeluaran pembiayaan dalam APBN/APBD selama satu (1) periode pelaporan. SILPA menjadi indikator yang mengambarkan efisiensi pengeluaran pemerintah. Pemerintah daerah juga dapat memanfaatkan SILPA tahun sebelumnya untuk membiayai kegiatannya dalam rangka mensejahterakan masyarakat (Rudi, 2017).

SILPA hanya akan terbentuk jika terjadi surplus pada APBD sekaligus terjadi pembiayaan neto yang positif, dimana komponen penerimaan akan lebih besar dibandingkan dengan komponen pengeluaran pembiayaan (Litbang, 2008). Berdasarkan UU No. 32 Tahun 2004 tentang Perimbangan Keuangan Pemerintahan Pusat dan Daerah, SILPA hanya dapat digunakan apabila defisit APBN dan APBD mencapai 3\% dari PDB tahun bersangkutan. Menentukan SILPA dalam Laporan Realisasi Anggaran dihitung berdasarkan total pemasukan daerah dikurangi dengan total pengeluaran daerah.

\section{Pengaruh DAU terhadap Belanja Modal}

Berdasarkan UU No. 33 Tahun 2004 tentang perimbangan keuangan antara pemerintah pusat dan pemerintah daerah menyatakan Dana Alokasi Umum, selanjutnya disebut DAU adalah dana yang berasal dari pendapatan APBN, dialokasikan dengan maksud pemerataan kemampuan keuangan antar-daerah yang digunakan untuk mendanai kebutuhan daerah dalam rangka pelaksanaan desentralisasi. DAU berasal dari transfer APBN yang dialokasikan dengan maksud pemerataan keuangan antar daerah dan untuk membiayai kebutuhan pengeluarannya dalam rangka pelaksanaan desentralisasi.

Farah (2011) dalam rangka perimbangan keuangan antara pemerintah pusat dan daerah. Dengan hal itu, akan terjadi transfer yang cukup signifikan di dalam APBN dari 
pemerintah pusat ke pemerintah daerah, sehingga pemerintah daerah dapat secara leluasa menggunakan DAU untuk memberikan pelayanan yang lebih baik kepada masyarakat. Farah (2011) Dana Alokasi Umum berpengaruh positif terhadap pengalokasian anggaran belanja modal, yang artinya semakin besar dana alokasi umum yang dialokasikan pemerintahan pusat kepada daerah maka semakin tinggi anggaran belanja modal yang dapat digunakan oleh pemerintahan daerah. Sejalan dengan penelitian Wandira (2013), Wimpi (2017), Rudi (2017), Made (2018), Widya (2018), Rendy (2018) dan Fiona (2013) yang menyatakan dana alokasi umum berpengaruh positif terhadap belanja modal. Hal ini disebabkan dengan adanya transfer dana alokasi umum dari pemerintahan pusat maka pemerintahan daerah dapat mengalokasikan pendapatannya untuk membiayai belanja modal.

$\mathbf{H}_{\mathbf{1}}$ : DAU berpengaruh positif sigfnifikan terhadap belanja modal

\section{Pengaruh PAD terhadap Belanja Modal}

Berdasarkan UU No. 33 Tahun 2004 tentang perimbangan keuangan antara pemerintah pusat dan pemerintah daerah menjelaskan bahwa pendapatan asli daerah, selanjutnya disebut PAD merupakan pendapatan yang diperoleh daerah dipungut berdasarkan peraturan daerah sesuai dengan peraturan perundang-undangan yang berlaku. Farah (2011) Pemerintah daerah (agent) bertanggung jawab kepada masyarakat (principal) karena masyarakat telah melaksanakan kewajibannya melalui pajak, retribusi, dan lain-lain. Pendapatan asli daerah memiliki hubungan dengan pengalokasian belanja modal, akan tetapi tidak semua daerah yang berpendapatan tinggi diikuti dengan pertumbuhan ekonomi yang lebih baik.

Tingginya tingkat produktivitas suatu masyarakat yang disebabkan oleh sarana dan prasarana yang memadai, ini akan berdampak pada menariknya minat investor untuk menanamkan modalnya pada daerah tersebut yang pada akhirnya akan meningkatkan pendapatan asli daerah. Made (2018) menyatakan pendapatan asli daerah merupakan faktor penentu dalam menentukan anggaran belanja modal dimana alokasi belanja modal disesuaikan dengan kebutuhan serta mempertimbangkan PAD yang diterima. Berdasarkan hasil penelitian Wandira (2013), Fiona (2013), Wimpi (2017), Rudi (2017), Made (2018), dan Widya (2018) juga menyatakan Pendapatan Asli Daerah berpengaruh positif terhadap anggaran belanja modal.

$\mathbf{H}_{2}$ : PAD berpengaruh positif signifikan terhadap belanja modal

\section{Pengaruh DBH terhadap Belanja Modal}

Berdasarkan UU No. 33 Tahun 2004 menyatakan Dana Bagi Hasil (DBH) merupakan dana yang berasal dari pendapatan APBN dan dialokasikan kepada daerah berdasarkan angka persentase yang digunakan untuk mendanai kebutuhan daerah dalam rangka pelaksanaan desentralisasi. Widya (2018) dana bagi hasil merupakan sumber pendapatan daerah yang cukup potensial dan menjadi salah satu modal dasar pemerintah daerah dalam mendapatkan dana pembangunan serta memenuhi belanja daerah yang bukan berasal dari PAD selain DAU. Wandira (2013) dana bagi hasil berpengaruh terhadap belanja modal, hal ini disebabkan oleh proporsi dana bagi hasil yang besar seiring dengan meningkatnya anggaran belanja modal. Rudi (2017), dan Widya (2018) menyatakan dana bagi hasil berpengaruh secara signifikan terhadap belanja modal. Berdasarkan landasan teori dan hasil penelitian sebelumnya, maka hipotesis dalam penelitian ini yaitu:

$\mathbf{H}_{3}$ : DBH berpengaruh positif signifikan terhadap Belanja Modal

\section{SILPA Memoderasi Pengaruh DAU Terhadap Belanja Modal}

Dana Alokasi Umum merupakan konsekuensi adanya penyerahan kewenangan pemerintahan pusat kepada pemerintahan daerah (Farah, 2011). Dalam meningkatkan 
pelayanan publik DAU harus dititikberatkan terhadap belanja modal, hal ini juga sesuai dengan teori fund accounting yang menyatakan bahwa pendapatan harus dibelanjakan untuk tujuan yang ditetapkan yaitu peningkatan pelayanan publik. SILPA tahun sebelumnya yang merupakan penerimaan pembiayaan akan digunakan untuk menutupi defisit anggaran apabila realisasi pendapatan lebih kecil daripada realisasi belanja, untuk mendanai pelaksanaan kegiatan lanjutan atas beban belanja langsung baik itu belanja barang dan jasa, belanja modal, dan belanja pegawai serta mendanai kewajiban lainnya yang sampai dengan ahir tahun anggaran belum diselesaikan (Widya, 2018).

Sisa Lebih Pembiayaan Anggaran tahun sebelumnya akan mempengaruhi jumlah transfer DAU terhadap daerah guna menentukan tingkat besaran belanja modal. Pengaruh DAU terhadap belanja modal dimoderasi oleh SILPA. Berdasarkan uraian diatas, maka hipotesis keempat dari penelitian ini adalah:

H4: SILPA memoderasi pengaruh DAU terhadap belanja modal

\section{SILPA Memoderasi Pengaruh PAD Terhadap Belanja Modal}

Menurut Made (2018) Pendapatan Asli Daerah berpengaruh positif terhadap alokasi belanja modal. Pendapatan Asli Daerah merupakan faktor penting dalam menentukan belanja modal. Penyusunan APBD dimana alokasi belanja modal harus disesuaikan dengan kebutuhan dan mempertimbangkan PAD yang diterima. Pemanfaatan PAD yang baik disertai dengan peningkatan PAD maka akan meningkatkan belanja modal pada daerah tersebut (Fiona, 2013). Berdasarkan Permendagri No. 21 Tahun 2011 tentang Pedoman Pengelolaan Keuangan Daerah, SILPA mencakup pelampauan penerimaan PAD, pelampauan penerimaan dana perimbangan, pelampauan penerimaan lain-lain pendapatan daerah yang sah, pelampauan penerimaan pembiayaan, penghematan belanja, kewajiban kepada pihak ketiga sampai dengan ahir tahun belum terselesaikan, dan sisa dana kegiatan lanjutan.

Ada tidaknya SILPA dan besar kecilnya sangat tergantung pada tingkat belanja yang dilakukan pemerintah daerah serta kinerja pendapatan daerah (Widya, 2018). Terjadinya SILPA memberikan indikator positif guna meningkatnya pembiayaan di daerah dalam memenuhi kebutuhan belanja modal. SILPA memoderasi hubungan antara PAD terhadap belanja modal. Berdasarkan uraian diatas, maka hipotesis kelima dari penelitian ini adalah:

$\mathbf{H}_{5}$ : SILPA memoderasi pengaruh PAD terhadap belanja modal

\section{SILPA Memoderasi Pengaruh DBH Terhadap Belanja Modal}

Berdasarkan hasil penelitian Wandira (2013) menyatakan bahwa dana bagi hasil berpengaruh positif terhadap belanja modal. Daerah yang mendapatkan DBH yang besar cenderung memiliki belanja modal yang besar pula. Dana bagi hasil menjadi salah satu sumber penerimaan daerah yang cukup potensial serta modal dasar bagi pemerintah daerah dalam mendapatkan dana pembangunan dan memenuhi belanja daerah yang bukan berasal dari PAD selain DAU dan DAK. Dalam APBD SILPA tahun anggaran sebelumnya merupakan salah satu bagian komponen penerimaan daerah. SILPA yang signifikan tinggi akan memberikan dorongan bagi pemerintah daerah untuk meningkatkan belanja modalnya sehingga terjadi efisiensi anggaran karena dana yang menganggur dapat digunakan baik untuk pengadaan aset, pembangunan infrastruktur, dan lainnya. SILPA memoderasi pengaruh DBH terhadap belanja modal. Berdasarkan uraian diatas, maka hipotesis keenam dari penelitian ini adalah:

$\mathbf{H}_{6}$ : SILPA memoderasi pengaruh DBH terhadap belanja modal 


\section{METODE PENELITIAN}

\section{Jenis Penelitian}

Penelitian ini menggunakan jenis penelitian kuantitatif dan termasuk kedalam penelitian kausatif. Penelitian kausatif yaitu penelitian yang menganalisis pengaruh antara suatu variabel terhadap variabel lainnya (Sugiyono, 2012). Penelitian ini menjelaskan pengaruh Dana Alokai Umum (DAU), Pendapatan Asli Daerah (PAD), dan Dana Bagi Hasil (DBH) terhadap belanja modal dengan Sisa Lebih Pembiayaan Anggaran (SILPA) sebagai variabel pemoderasi pada pemerintah provinsi se-indonesia periode 2015-2019.

Populasi dan sampel dalam penelitian ini adalah seluruh Pemerintahan Provinsi SeIndonesia dari tahun 2015-2019 yang terdiri dari 34 Provinsi dengan jumlah 170 data yang di dapat dari Laporan Realisasi APBD tahun 2015-2019. Data dalam penelitian ini adalah data sekunder yang terdiri dari data DAU, PAD, DBH, SILPA dan data Belanja Modal yang diperoleh dari situs Dirjen Perimbangan Keuangan Pemerintah Daerah (DJPK). Teknik pengumpulan data yang digunakan yaitu dengan cara studi dokumentasi data diperoleh dari Dirjen Perimbangan Keuangan Pemerintah Daerah (www.djpk.kemenkeu.go.id). Selain itu, peneliti juga melakukan studi literatur melalui buku serta jurnal yang berkaitan dengan masalah yang diteliti.

\section{Pengukuran Variabel \\ Belanja Modal}

Belanja modal merupakan belanja dari pemerintah daerah yang manfaatnya lebih dari 1 (satu) tahun anggaran dan akan menambah aset ataupun kekayaan daerah serta selanjutnya akan menambah belanja yang bersifat rutin seperti biaya pemeliharaan pada kelompok belanja administrasi umum.

\section{Belanja Modal $=$ Belanja Tanah + Belanja Peralatan dan Mesin +Belanja Gedung dan Bangunan + Belanja Jalan, Irigasi dan Jaringan+ Belanja Aset Lainnya}

Sumber : PP No. 71 Tahun 2010

\section{Dana Alokasi Umum (DAU)}

Dana alokasi umum merupakan dana yang berasal dari pendapatan APBN, dialokasikan dengan maksud pemerataan kemampuan keuangan antar daerah yang digunakan untuk mendanai kebutuhan daerah dalam rangka pelaksanaan desentralisasi. Dana alokasi umum baik untuk pemerintahan provinsi maupun pemerintahan kabupaten/kota dapat dinyatakan sebagi berikut :

\section{DAU = Celah Fiskal + Alokasi Dasar \\ Sumber : UU No.33 Tahun 2004}

Keterangan :

Celah Fiskal $=$ kebutuhan fiskal - kapasitas fiskal

\section{Pendapatan Asli Daerah (PAD)}

Pendapatan asli daerah merupakan penerimaan yang berasal dari sumber-sumber daerah itu sendiri, yang dipungut berdasarkan peraturan daerah dengan peraturan perundang- undangan yang berlaku yang terdiri dari Hasil Pajak Daerah (HDP), Retribusi Daerah (RD), Pendapatan dari Laba Perusahaan Daerah (PLPB), dan lain- lain Pendapatan yang Sah (LPS). Rumus dalam menentukan PAD yaitu:

$$
\text { PAD }=\text { HPD }+ \text { RD }+ \text { PLPD }+ \text { LPS }
$$

Sumber : UU No.33 Tahun 2004 
Keterangan :

PAD $=$ Pendapatan Asli Daerah,

HPD $=$ Hasil Pajak Daerah,

$\mathrm{RD}=$ Retribusi Daerah,

PLPD = Pendapatan dari Laba Perusahaan Daerah,

LPS = Lain-lain Pendapatan yang Sah

\section{Dana Bagi Hasil (DBH)}

Dana bagi hasil merupakan dana yang berasal dari pendapatan APBN dan dialokasikan kepada daerah berdasarkan angka persentase yang digunakan untuk mendanai kebutuhan daerah dalam rangka pelaksanaan desentralisasi.

\section{SILPA (Sisa Lebih Pembiayaan Anggaran)}

Sisa Lebih Pembiayaan Anggaran atau SILPA merupakan selisih antara realisasi pendapatan LRA dan belanja serta penerimaan dan pengeluaran selama satu (1) periode pelaporan. Menentukan SILPA dalam Laporan Realisasi Anggaran dihitung berdasarkan total pemasukan daerah dikurangi dengan total pengeluaran daerah.

\section{Teknik Analisis Data}

Analisis data ini bertujuan dalam mengetahui peran dari masing-masing variabel bebas (independent) dalam mempengaruhi variabel terikat (dependent). Model regresi MRA yang digunakan:

$$
\begin{aligned}
& \mathrm{Y}=\alpha+\beta 1 \mathrm{DAU}+\beta 2 P A D+\beta 3 D B H+\beta 4 D A U * \text { SILPA }+\beta 5 P A D * \text { SILPA }+ \\
& \beta 6 D B H * \text { SILPA }+e
\end{aligned}
$$

\section{HASIL DAN PEMBAHASAN Analisis Statistik Deskriptif}

\begin{tabular}{|c|c|c|c|c|c|}
\hline \multicolumn{6}{|c|}{ Descriptive Statistics } \\
\hline & $\mathrm{N}$ & Minimum & Maximum & Mean & Std. Deviation \\
\hline DAU & 170 & Rp. 0 & Rp. 3.998.431.715 & Rp. 142.849 .939 & Rp. 724.464 .160 \\
\hline PAD & 170 & Rp. 236.054.304 & Rp. 45.707.400.003 & Rp. 4.340.447.176 & Rp. 7.748 .896 .649 \\
\hline $\mathrm{DBH}$ & 170 & Rp. 0 & Rp. 16.847.489.450 & Rp. 920.859 .869 & Rp. 2.241.563.405 \\
\hline SILPA & 170 & Rp. 8.912.219 & Rp. 13.165.982.127 & Rp. 829.539.014 & Rp. 1.591.772.204 \\
\hline BM & 170 & Rp. 229.776.980 & Rp. 14.118.608.087 & Rp. 1.407 .427 .715 & Rp. 1.866.160.609 \\
\hline Valid N (listwise) & 170 & & & & \\
\hline
\end{tabular}

Tabel 4.4 Analisis Statistik Deskriptif Variabel Penelitian (dalam jutaan)

Sumber: Data Sekunder yang diolah, 2020

Berdasarkan tabel diatas menunjukan bahwa rata-rata nilai belanja modal sebesar Rp. 1.407.427.715.665, standard deviation sebesar Rp. 1.866.160.609.876, sedangkan nilai minimum dan maksimumnya masing-masing sebesar Rp. 229.776.980.689 dan Rp. 14.118.608.087.643. Nilai DAU menunjukan rata-rata sebesar Rp. 142.849.939.281,94, standar deviasi sebesar Rp. 724.464.160.707,979, sedangkan nilai minimum yaitu Rp. 0 dan nilai maksimum sebesar Rp. 3.998.431.715.000.

Nilai PAD menunjukan rata-rata sebesar Rp. 4.340.447.176.672,53, standar deviasi sebesar Rp. 7.748.896.649.362,220, sedangkan nilai minimum yaitu Rp. 236.054.304.107 dan nilai maksimum yaitu Rp. 45.707.400.003.802. Nilai DBH menunjukan rata-rata sebesar Rp. 920.859.869.015,08, standar deviasi sebesar Rp. 2.241.563.405.502,140, sedangkan nilai 
minimum yaitu Rp. 0 dan nilai maksimum sebesar Rp. 16.847.489.450.263. Nilai SILPA menunjukan rata-rata sebesar Rp. 829.539.014.576,12, standar deviasi sebesar Rp. 1.591.772.204.518,020, sedangkan nilai minimum yaitu $\mathrm{Rp}$. 8.912.219.257, dan nilai maksimum yaitu Rp. 13.165.982.127.532.

\section{Uji Asumsi Klasik}

\section{Uji Normalitas}

Uji normalitas dilakukan dengan tujuan untuk mengetahui apakah dalam model regresi variabel terdistribusi secara normal. Alat uji yang dapat digunakan untuk meguji data berdistribusi normal adalah One Sample Komogorov-Smirnov (KS). Pengujian normalitas menggunakan uji Kolmogorv-Smirnov yaitu jika nilai signifikansi $>0,05$ maka Ho diterima (berdistribusi normal) sedangkan jika nilai signifikansi $<0,05$ maka Ho ditolak (tidak berdistribusi normal) (Ghozali, 2011). Berdasarkan hasil uji normalitas menunjukan bahwa nilai sig $>0,05$ yaitu $0,200>0,05$. Jadi dapat disimpulkan bahwa data terdistribusi secara normal.

\section{Uji Multikolinieritas}

Uji Multikolinearitas dilakukan dengan bertujuan untuk menguji apakah dalam model regresi ditemukan adanya korelasi atau hubungan antara variabel bebas (independent). Model regresi yang baik seharusnya tidak akan terjadi korelasi diantara variabel bebas (independent) (Ghozali, 2011: 105). Untuk mengetahui terjadinya multikolinearitas dalam model regresi dapat dilihat dari nilai VIF dan Tolerance. Apabila nilai Tolerance lebih dari 10 atau $>0,1$ dan $V I F<10$ maka dapat dikatakan tidak terdapat gejala multikolinearitas. Berdasarkan hasil uji multikolinieritas menunjukan bahwa nilai VIF masing-masing variabel memiliki nilai VIF $<10$ dan nilai Tolerance $>0,1$ sehingga bisa dikatakan model regresi telah memenuhi syarat multikolinieritas.

\section{Uji Autokorelasi}

Uji Autokolerasi bertujuan dalam menguji apakah pada model regresi linear terdapat korelasi antara kesalahan pengganggu pada periode $t$ dengan kesalahan pengganggu pada periode ke t1 (sebelumnya) (Ghozali, 2011:110). Uji autokorelasi akan terjadi apabila terdapat penyimpangan terhadap suatu observasi oleh penyimpangan yang lain atau terjadi korelasi diantara observasi menurut waktu dan tempat. Model regresi yang baik seharusnya tidak terjadi autokorelasi. Berdasarkan hasil pengujian autokorelasi menunjukkan bahwa nilai Durbin Watson sebesar 1,974. Angka tersebut menunjukan bahwa nilai D-W berada diantara -2 sampai $+2(-2<\mathrm{D}-\mathrm{W}<+2)$. Nilai D-W berada diantara $-2<1,974<+2$. Berdasarkan hasil pengujian tersebut dapat disimpulkan tidak terjadi autokorelasi.

\section{Uji Heteroskedastisitas}

Uji Heteroskedastisitas bertujuan menguji apakah pada suatu model regresi terjadi ketidaksamaan variance dari residual satu pengamatan ke pengamatan lain tetap, maka disebut homokedastisitas dan sebaliknya jika terjadi perberbedaan maka disebut heteroskedastisitas. Model regresi yang seharusnya homokedastisitas atau tidak terjadi heteroskedastisitas. Apabila nilai signifikan $>0,05$ maka tidak terjadi gejala heteroskedastisitas. Berdasarkan hasil pengujian heteroskedastisitas menunjukan bahwa hasil perhitungan masing-masing variabel menunjukan nilai sig $>0,05$. Jadi dapat disimpulakan penelitian ini bebas dari gejala heteroskedastisitas dan layak untuk diteliti. 


\section{Pengujian Hipotesis}

Pengujian hipotesis pada penelitian ini menggunakan Moderated Regression Analysis (MRA), berikut hasil uji Moderated Regression Analysis (MRA):

\section{Model Regresi /Moderated Regression Analysis (MRA)}

Tabel Hasil Analisis Moderated Regression Analysis (MRA)

\begin{tabular}{|c|c|c|c|c|c|c|}
\hline \multicolumn{7}{|c|}{ Coefficients $^{a}$} \\
\hline \multirow{2}{*}{\multicolumn{2}{|c|}{ Model }} & \multicolumn{2}{|c|}{$\begin{array}{l}\text { Unstandardized } \\
\text { Coefficients }\end{array}$} & \multirow{2}{*}{$\begin{array}{l}\text { Standardized } \\
\text { Coefficients } \\
\text { Beta }\end{array}$} & \multirow[b]{2}{*}{$\mathrm{t}$} & \multirow[b]{2}{*}{ Sig. } \\
\hline & & $\mathrm{B}$ & Std. Error & & & \\
\hline \multirow[t]{8}{*}{1} & (Constant) & $-58,202$ & 44,062 & & $-1,321$ & ,188 \\
\hline & DAU & 3,129 & 1,792 & 2,257 & 1,746 &, 083 \\
\hline & PAD & 650 & 877 & 1,141 & ,741 &, 460 \\
\hline & DBH &,- 855 & ,684 & $-1,752$ & $-1,250$ & ,213 \\
\hline & SILPA & 2,494 & 1,621 & 5,280 & 1,539 & , 126 \\
\hline & $\mathrm{X} 1 \mathrm{Z}$ &,- 104 &, 066 & $-6,980$ & $-1,582$ & ,116 \\
\hline & $\mathrm{X} 2 \mathrm{Z}$ &,- 019 & 032 & $-1,777$ &,- 582 &, 561 \\
\hline & $\mathrm{X} 3 \mathrm{Z}$ & 039 & 026 & 3,828 & 1,536 & 127 \\
\hline \multicolumn{7}{|c|}{ a. Dependent Variable: BM } \\
\hline $\mathrm{R}$ & - & & & & & 0,664 \\
\hline $\mathrm{F}$ & : & & & & & 46,658 \\
\hline
\end{tabular}

Sumber: Data Sekunder yang diolah, 2020

Nilai konstanta bernilai negatif adalah sebesar -58,202 yang berarti bahwa apabila variabel DAU, PAD, DBH, SILPA, interaksi DAU terhadap SILPA, interaksi PAD terhadap SILPA, dan interaksi DBH terhadap SILPA di anggap konstan (0), maka Belanja Modal tetap sebesar -58,202. Koefisien MRA variabel DAU bernilai positif sebesar 3,129 bermakna bahwa setiap kenaikan DAU pada Provinsi di Indonesia sebesar 1 satuan, maka akan menaikan Belanja Modal sebesar 3,129 satuan. Koefisien MRA variabel PAD bernilai positif sebesar 0,650 bermakna bahwa setiap kenaikan PAD pada Provinsi di Indonesia sebesar 1 satuan, maka akan menaikan Belanja Modal sebesar 0,650 satuan. Koefisien MRA variabel DBH bernilai negatif sebesar $-0,855$ bermakna bahwa setiap kenaikan DBH pada Provinsi di Indonesia sebesar 1 satuan, maka akan menurunkan Belanja Modal sebesar -0,855 satuan.

Koefisien MRA variabel interaksi DAU terhadap SILPA bernilai negatif sebesar 0,104, bermakna bahwa setiap kenaikan interaksi DAU terhadap SILPA pada Provinsi di Indonesia sebesar 1 satuan, maka akan menurunkan Belanja Modal sebesar -0,104 satuan. Koefisien MRA variabel interaksi PAD terhadap SILPA bernilai negatif sebesar $-0,019$, bermakna bahwa setiap kenaikan interaksi PAD terhadap SILPA pada Provinsi di Indonesia sebesar 1 satuan, maka akan menurunkan Belanja Modal sebesar -0,019 satuan. Koefisien MRA variabel interaksi DBH terhadap SILPA bernilai positif sebesar 0,039, bermakna bahwa setiap kenaikan interaksi DBH terhadap SILPA pada Provinsi di Indonesia sebesar 1 satuan, maka akan menaikan Belanja Modal sebesar 0,039 satuan.

Berdasarkan tabel diatas untuk uji koefisien determinan (R2) dapat dilihat bahwa besarnya nilai Adjusted $\mathrm{R}^{2}$ adalah 0,664 atau 66,4\%. Hal ini berarti bahwa besar pengaruh dapat dijelaskan oleh variasi dari variabel independen DAU, PAD, dan DBH serta Variabel moderasi SILPA terhadap variabel dependen (Belanja Modal) adalah 66,4\%. Sedangkan sisanya 33,6\% (100\% -66,4\%) dipengaruhi oleh variabel lain yang tidak diteliti pada penelitian ini. Sesuai dengan tabel diatas untuk uji simultan (uji F statistik) dapat diketahui

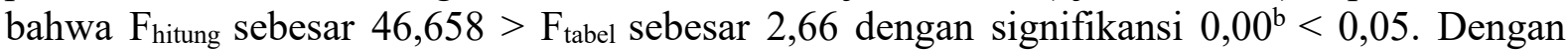
hasil ini menunjukan hipotesis alternatif $\mathrm{H}_{\mathrm{a}}$ diterima dan $\mathrm{H}_{0}$ ditolak. Maka dapat disimpulkan bahwa secara bersama-sama variabel DAU (X1), PAD (X2), DBH (X3), dan SILPA (Z) berpengaruh secara signifikan terhadap variabel Y (Belanja Modal). Pada uji hipotesis/uji 
statistik t menunjukan bahwa hipotesis pertama di terima dengan syarat tingkat signifikan $10 \%$ atau sig $>0,1$ sedangkan hipotesis kedua sampai hipotesis keenam di tolak.

\section{PEMBAHASAN HASIL PENELITIAN}

\section{Pengaruh Dana Alokasi Umum (DAU) terhadap Belanja Modal}

Berdasarkan hasil penelitian yang dilakukan pada pemerintahan provinsi di Indonesia tahun 2015-2019, ditemukan bahwa hipotesis (H1) diterima. Hasil penelitian ini menunjukan bahwa Dana Alokasi Umum berpengaruh signifikan terhadap belanja modal. Sejalan dengan penelitian yang dilakukan Rendy (2018) dimana hasil penelitiannya yaitu Dana Alokasi Umum memiliki pengaruh yang signifikan terhadap belanja modal. Wimpi (2017) Dana Alokasi Umum berpengaruh signifikan terhadap Belanja Modal pada Kabupaten dan Kota di Pulau Jawa Tahun 2013. Rudi (2017), Wandira (2013), Fiona (2013), dan Farah (2011) dimana hasil penelitiannya yaitu dana alokasi umum berpengaruh signifikan terhadap belanja modal.

Penelitian ini menunjukan hasil yang signifikan disebabkan karena semakin tinggi dana alokasi Umum yang diterima oleh pemerintahan provinsi maka penggunaan terhadap belanja modal akan meningkat. Sesuai dengan fungsi dana alokasi umum itu sendiri yaitu dialokasikan dengan tujuan pemerataan kemampuan keuangan antar daerah untuk mendanai kebutuhan daerah dalam rangka pelaksanaan desentralisasi. Selain itu, Dana Alokasi Umum bepengaruh signifikan terhadap belanja modal juga dikarenakan sejak tahun 2015 sampai tahun 2019 pemerintah pusat mengalokasikan dana alokasi umum ke setiap pemerintahan provinsi secara merata.

\section{Pengaruh Pendapatan Asli Daerah (PAD) terhadap Belanja Modal}

Diperoleh hasil penelitian bahwa hipotesis kedua (H2) ditolak. Hasil ini menunjukan bahwa pendapatan asli daerah tidak berpengaruh terhadap belanja modal. Sejalan dengan penelitian yang dilakukan oleh Rendy Armando Kakasih (2018) yang menyatakan bahwa Pendapatan asli daerah tidak memiliki pengaruh signifikan terhadap belanja modal. Hal ini berarti bahwa kabupaten dan kota dengan pendapatan asli daerah yang besar tidak memiliki belanja modal yang besar, disebabkan karena PAD lebih banyak digunakan untuk membiayai belanja lain, seperti belanja rutin/belanja operasional. Hasil penelitian ini juga sejalan dengan penelitian terdahulu yang dilakukan oleh Widya Yana (2018) yang menyatakan bahwa secara parsial Pendapatan Asli Daerah tidak memiliki pengaruh terhadap Belanja Modal Daerah pada Kabupaten/ Kota di Provinsi Aceh Tahun 2015-2016.

Erdi Adyatma (2015) dimana pendapatan asli daerah tidak berpengaruh terhadap Belanja Modal, hal ini dapat diartikan bahwa semakin tinggi pendapatan asli daerah maka pengeluaran pemerintah atas belanja modal belum tentu juga akan semakin tinggi. Berdasarkan teori keagenan, dimana hubungan kontraktual antara Agent (masyarakat) dengan Principal (pemerintah) dalam konteks pendapatan asli daerah dapat dilihat dari kemampuan dan tanggungjawab pemerintah daerah untuk memberikan pelayanan publik yang baik sekaligus meningkatkan kesejahteraan masyarakat melalui anggaran belanja modal yaitu dengan menyediakan sarana dan prasarana yang memadai dan dibiayai dari belanja modal yang di anggarkan setiap tahunnya, sedangkan belanja modal itu sendiri sumber pembiayaannya dari pendapatan asli daerah (Erdi, 2015).

Pada penelitian ini menunjukan hasil yang tidak signifikan disebabkan karena peningkatan pendapatan asli daerah tidak sebanding dengan peningkatan belanja modal. Berdasarkan hasil analisis terdapat 25 provinsi dimana pendapatan asli daerah meningkat dari tahun 2015-2019 akan tetapi tidak diikuti dengan peningkatan belanja modal, salah satunya adalah provinsi Sumatera Utara yang mana pendapatan asli daerah rata-rata setiap tahunnya 4,8 triliun sampai 5,7 triliun sedangkan belanja modal rata-rata 932,2 Miliar sampai dengan 
1,2 Trilun. Provinsi Sumatera Utara lebih banyak menggunakan belanja daerahnya untuk belanja pegawai dan belanja hibah dibandingkan dengan belanja modal.

\section{Pengaruh Dana Bagi Hasil (DBH) terhadap Belanja Modal}

Berdasarkan hasil analisis statistik dalam penelitian ini, ditemukan bahwa hipotesis ketiga (H3) ditolak. Hal ini menunjukan bahwa Dana Bagi Hasil (DBH) tidak berpenagruh terhadap Belanja Modal. Dengan hasil tersebut dapat diketahui bahwa semakin besar Dana Bagi Hasil yang diperoleh dari tranfer pemerintahan pusat ke daerah maka penggunaan terhadap kebutuhan Belanja Modal akan semkin kecil. Sejalan dengan penelitian yang dilakukan oleh Widya Yana (2018), Waskito (2019), dan Desak Gede Yudi (2017) yang menyatakan bahwa dana bagi hasil tidak berpengaruh signifikan terhadap belanja modal.

Hal ini dikarenakan sumber dana bagi hasil yaitu sumber daya alam dan pajak mengalami fluktuasi setiap tahunnya, sehingga dana bagi hasil tidak tergantung pada anggaran belanja modal pada suatu daerah dan pelayanan publik yang direalisasikan dengan belanja modal masih rendah. Penelitian ini menunjukan hasil yang tidak signifikan disebabkan karena perolehan dana bagi hasil setiap derah pada umumnya lebih rendah dibandingkan jumlah realisasi belanja modal. Terdapat 3 Provinsi yang memperoleh dana bagi hasil yang lebih besar dibandingkan belanja modal yaitu DKI Jakarta, Kalimantan Timur dan Papua Barat. Daerah yang menerima dana bagi hasil yang lebih besar sebanding dengan pendapan daerah itu sendiri.

\section{Pengaruh Dana Alokasi Umum (DAU) terhadap Belanja Modal dengan Sisa Lebih Pembiayaan Anggaran (SILPA) sebagai variabel Pemoderasi}

Hasil penelitian menunjukan hipotesis keempat (H4) ditolak. Hal ini menunjukan bahwa SILPA tidak memoderasi pengaruh DAU terhadap belanja modal. Sejalan dengan penelitian Widya Yana (2018) yaitu secara parsial SILPA tidak mampu memoderasi (memperlemah) hubungan antara PAD, DAU, DBH, DOK terhadap belanja modal. Penelitian ini menunjukan bahwa SILPA tidak memoderasi pengaruh DAU terhadap belanja modal, disebabkan karena jumlah SILPA yang besar tahun sebelumnya mengakibatkan rendahnya transfer DAU dari pemerintahan pusat ke daerah. Dana Alokasi Umum yang rendah dengan tujuan agar tidak terjadi SILPA yang besar di tahun berjalan. Sesuai dengan UU No. 33 Tahun 2004 yang menyatakan bahwa alokasi dana alokasi umum bagi daerah yang memiliki potensi fiskalnya besar tetapi dengan kebutuhan fiskalnya rendah akan memperoleh transfer dana alokasi umum yang relatif rendah pula.

\section{Pengaruh Pendapatan Asli Daerah (PAD) terhadap Belanja Modal dengan Sisa Lebih Pembiayaan Anggaran (SILPA) sebagai variabel Pemoderasi}

Hasil penelitian ini menunjukan bahwa hipotesis kelima (H5) ditolak. Hal ini menunjukan bahwa SILPA tidak memoderasi (memperlemah) pengaruh PAD terhadap Belanja Modal. Sejalan dengan penelitian Widya Yana (2018) yaitu secara parsial SILPA tidak mampu memoderasi (memperlemah) hubungan antara PAD, DAU, DBH, DOK terhadap belanja modal. Berdasarkan hasil penelitian ini SILPA tidak memoderasi hubungan PAD terhadap belanja modal, melainkan memperlemah hubungan keduanya. Dengan adanya SILPA tahun sebelumnya akan memperlemah hubungan antara PAD terhadap belanja modal.

SILPA termasuk kedalam post pembiayaan dan bukan merupakan bagian dari penerimaan PAD. SILPA merupakan salah satu sumber pendanaan belanja modal, SILPA tahun anggaran sebelumnya bisa dijadikan pertimbangan dalam melakukan alokasi belanja modal langsung maupun belanja modal untuk pembangunan daerah (Sandra, 2018). Semakin tinggi perolehan penerimaan daerah dalam hal ini PAD maka kemungkinan besar akan terjadi SILPA jika realisasi belanja modal kecil. Salah satu cara yang dilakukan pemerintah agar 
anggaran lebih efisien yaitu dengan meningkatkan realisasi belanja modal dibandingkan dengan belanja pegawai.

\section{Pengaruh Dana Bagi Hasil (DBH) terhadap Belanja Modal dengan Sisa Lebih Pembiayaan Anggaran (SILPA) sebagai variabel Pemoderasi}

Diperoleh hasil penelitian bahwa hipotesis keenam (H6) ditolak. Hal ini menunjukan bahwa SILPA tidak memoderasi (memperlemah) pengaruh DBH terhadap belanja modal. Sejalan dengan penelitian terdahulu yaitu Widya Yana (2018) hasil penelitiannya, secara parsial SILPA tidak mampu memoderasi (memperlemah) hubungan antara PAD, DAU, DBH, DOK terhadap belanja modal. Hasil penelitian ini menjelaskan bahwa SILPA tidak memoderasi pengaruh DBH terhadap belanja modal, melainkan memperlemah hubungan kedunaya. Tingginya SILPA tidak akan memperkuat hubungaan DBH terhadap belanja modal karena SILPA yang tinggi menyebabkan alokasi DBH kecil, hal ini mempertimbangkan efisiensi anggaran.

Penyaluran dana bagi hasil dilakukan berdasarkan prinsip based on actual revenue yang artinya adalah penyaluran dana bagi hasil berdasarkan realisasi penerimaan tahun anggaran berjalan (pasal 23 UU 33/2004) (www.djpk.kemenkeu.go.id). Semakin besar realisasi penerimaan tahun anggaran berjalan dalam hal ini termasuk SILPA tahun sebelumnya, maka anggaran DBH dari Pemerintahan Pusat akan semakin berkurang. Jika perolehan DBH tinggi dan tahun sebelumnya juga terjadi SILPA maka akan memperlemah hubungan DBH terhadap Belanja Modal karena salah satu yang menyebabkan terjadinya SILPA adalah pelampauan penerimaan dana perimbangan (DBH) atau yang di kenal dengan SILPA pasif.

\section{SIMPULAN DAN SARAN \\ Simpulan}

Berdasarkan hasil penelitian dan pengujian hipotesis yang telah dilakukan sebelumnya, maka kesimpulan penelitian ini adalalah:

1. Dana Alokasi Umum (DAU) berpengaruh signifikan terhadap belanja modal.

2. Pendapatan Asli Daerah (PAD) tidak berpengaruh terhadap belanja modal.

3. Dana Bagi Hasil (DBH) tidak berpengaruh terhadap belanja modal.

4. Sisa Lebih Pembiayaan Anggaran (SILPA) tidak memoderasi (memperlemah) pengaruh Dana Alokasi Umum (DAU) terhadap belanja modal.

5. Sisa Lebih Pembiayaan Anggaran (SILPA) tidak memoderasi (memperlemah) pengaruh Pendapatan Asli Daerah (PAD) terhadap belanja modal.

6. Sisa Lebih Pembiayaan Anggaran (SILPA) tidak memoderasi (memperlemah) pengaruh Dana Bagi Hasil (DBH) terhadap belanja modal.

\section{Keterbatasan}

Keterbatasan dalam penelitian ini adalah :

1. Penelitian ini hanya menggunakan variabel Dana Alokasi Umum, Pendapatan Asli Daerah, dan Dana Bagi Hasil sebagai variabel independen sehingga memberikan peluang bagi peneliti selanjutnya untuk menggunakan variabel lain.

2. Data penelitian yang digunakan hanya 5 tahun yaitu tahun 2015-2019.

3. Pada penelitian ini hanya variabel DAU yang berpengaruh terhadap variabel belanja modal sehingga dalam penelitian ini belum dapat menjelaskan hal apa saja yang mempengaruhi belanja modal.

4. Variabel moderasi dalam penelitian ini tidak mampu memperkuat (memoderasi) pengaruh Dana Alokasi Umum, Pendapatan Asli Daerah, dan Dana Bagi Hasil terhadap Belanja Modal. 
5. Penelititian ini hanya menggunakan Uji Moderated Regression Analysis (MRA) untuk menguji variabel independen dan interaksi variabel moderasi dengan variabel independen.

\section{Saran}

1. Bagi seluruh pemerintah daerah yang ada di Indonesia agar lebih mengoptimalkan penggunaan belanja modal, terutama untuk pembangunan infratruktur, jalan dan jaringan komunikasi di daerah.

2. Bagi peneliti selanjutnya sebaiknya menambahkan variabel lain yang dianggap dapat mempengaruhi belanja modal.

3. Bagi peneliti selanjutnya dapat menggunakan data terbaru dan menggunakan metode lain dalam menguji variabel moderasi.

\section{DAFTAR PUSTAKA}

Aditiya, N. Y., \& Dirgantari, N. (2017). Pengaruh Pendapatan Asli Daerah (PAD), Dana Alokasi Umum (DAU), Dana Alokasi Khusus (DAK) dan Sisa Lebih Pembiayaan Anggaran (SiLPA) terhadap Belanja Modal pada Kabupaten dan Kota di Jawa Tengah tahun 2013-2015. Kompartemen: Jurnal Ilmiah Akuntansi, 15(1).

Adyatma, E., \& Oktaviani, R. M. (2015). Pengaruh pendapatan asli daerah dan dana alokasi umum terhadap belanja modal dengan pertumbuhan ekonomi sebagai pemoderasi. Dinamika Akuntansi Keuangan Dan Perbankan, 4(2).

Arwati, D., \& Hardiati, N. (2013). Pengaruh Pertumbuhan Ekonomi, Pendapatan Asli Daerah, Dana Alokasi Umum terhdap Pengalokasian Anggaran Belanja Modal padaPemerintah Daerah Kabupaten/kota di Jawa Barat.”. In Seminar Nasional Teknologi Informasi dan Komunikasi Terapan (SEMANTIK). ISBN: 979-260266 (Vol. 6).

Djpk.kemenkeu.go.id.2020.“LRAAPBD2018”http:/www.djpk.kemenkeu.go.id/?p=5412 di akses 13 Oktober 2020.

Ghozali, I. (2011). Aplikasi analisis multivariate dengan program IBM.

Halim, A. (2004). Akuntansi keuangan daerah. Jakarta: Salemba Empat.

Hermawan, R. (2017). Pengaruh Pendapatan Asli Daerah (Pad), Dana Perimbangan, Dan Sisa Lebih Pembiayaan Anggaran (Silpa) Terhadap Belanja Modal (Studi pada Pemerintah Kabupaten/Kota di Provinsi Jawa Tengah Periode 20132015) (Doctoral dissertation, Universitas Muhammadiyah Surakarta).

Hulondalo.id. 2020."Realisasi Belanja APBN 2018 di Gorontalo Capai 92,68\%" https://www.google.co.id/amp/s/hulondalo.id/realisasi-belanja-apbn-2018-digorontalo-capai-9268-tapi/amp/ di akses 21 November 2020.

Indonesia, P. R. (2005). Peraturan Pemerintah Republik Indonesia no 55 tahun 2005 tentang Dana Perimbangan.

Indonesia, P. R. (2019). Peraturan Pemerintah Nomor 12 Tahun 2019 tentang Pengelolaan Keuangan Daerah. Sekretariat Negara. Jakarta.

Indonesia, R. (2003). Undang-Undang nomor 17 tahun 2003 tentang. Keuangan Negara.

Indonesia, R. (2004). Undang-Undang Republik Indonesia Nomor 33 tahun 2004 tentang. Perimbangan Keuangan antara Pemerintah Pusat dan Pemerintah Daerah.

Indonesia, R. (2005). Peraturan Pemerintah No. 58 Tahun 2005 tentang Pengelolaan Keuangan Daerah. Lembaran Negara RI Tahun, 140.

Jensen, M. C., \& Meckling, W. H. (1976). Theory of the firm: Managerial behavior, agency costs and ownership structure. Journal of financial economics, 3(4), 305-360. 
Kakasih, R. A., Kawung, G. M., \& Tumangkeng, S. Y. (2018). Pengaruh Pendapatan Asli Daerah Dan Dana Alokasi Umum Terhadap Belanja Modal Pada Kabupaten Dan Kota Di Provinsi Sulawesi Utara Periode 20019-2016. Efesiensi, 18(2).

Katadata.co.id. 2020."Belanja Modal Hanya 53\%, Bappenas Ingin Penyerapan AnggaranLebihAwal”https://www.google.com/amp/s/katadata.co.id/amp/febrinai skana/finansial/5e9a4c55840e0/belanja-modal-hanya-53-bappenas-inginpenyerapan-anggaran-lebih-awal di akses 21 November 2020.

Kawedar, W., Rohman, A., \& Handayani, S. (2008). Akuntansi sektor publik. Pendekatan Penganggaran Daerah dan Akuntansi Keuangan Daerah. Semarang: Badan Penerbit Universitas Diponegoro.

Keswando, R. (2016). Pengaruh Pendapatan Asli Daerah, Dana Alokasi Umum, Dana Alokasi Khusus, Dan Luas Wilayah Daerah Terhadap Alokasi Belanja Modal Studi Empiris Di Provinsi Jawa Timur. Jurnal Akuntansi dan Sistem Teknologi Informasi, 12(1).

M.akurat.co. 2020. "APBN Kaltim Turun $R p \quad 4$ Triliun Dibilang Bagus, Kok Bisa? ”https://www.google.com/amp/s/m.akurat.co/189155/apbn-kaltim-turun-rp4-triliun-dibilang-bagus-kok-bisa di akses 21 November 2020.

M.antaranews.com. 2020. "Mendagri sebut Silpa DKI Jakarta dan Aceh paling tinggi2018“https://www.google.com/amp/s/m.antaranews.com/amp/berita/92104

0/mendagri-sebut-silpa-dki-jakarta-dan-aceh-paling-tinggi-2018 di akses 21 November 2020.

Mardiasmo. (2014). Akuntansi Sektor Publik. Yogyakarta:ANDI

Nainggolan, B. R. M., \& Hantono, H. (2018). Pengaruh Pendapatan Asli Daerah Dan Dana Perimbangan Terhadap Belanja Modal Dengan Sisa Lebih Perhitungan Anggaran Sebagai Variabel Moderasi Pada Pemerintah Kota Dan Kabupaten Provinsi Sumatera Utara. Jurnal Akrab Juara, 3(1), 178-190.

Nomor, P. M. D. N. (21). Tahun 2011 Tentang Perubahan Kedua Atas Peraturan Menteri Dalam Negeri Nomor 13 Tahun 2006 Tentang. Pedoman Pengelolaan Keuangan Daerah.

Nomor, P. P. (71). Tahun 2010. Standar Akuntansi Pemerintahan.

Okynawa, S., Sulistyo, S., \& Mustikowati, R. I. (2018). Pengaruh Pendapatan Asli Daerah (PAD), Dana Alokasi Umum (DAU), Dan Sisa Lebih Pembiayaan Anggaran (SiLPA) Terhadap Belanja Modal Kabupaten/Kota Se-Jawa Timur (APBD Tahun Anggaran 2016). Jurnal Riset Mahasiswa Akuntansi, 6(1).

Priambudi, W. (2017). Pengaruh Pendapatan Asli Daerah dan Dana Alokasi Umum terhadap Belanja Modal pada Kabupaten dan Kota di Pulau Jawa Tahun 2013. Nominal: Barometer Riset Akuntansi dan Manajemen, 6(1), 136-147.

Purwanto, F. D. (2013). Pengaruh Pertumbuhan Ekonomi, Pendapatan Asli Daerah, dan Dana Alokasi Umum terhadap Belanja Modal Studi Kasus Kota dan Kabupaten di Jawa Tengah Tahun 2008-2011. Jurnal Universitas Negeri Yogyakarta.

Sari, D. G. Y. A., Kepramareni, P., \& Novitasari, N. L. G. (2017). Pengaruh Pertumbuhan Ekonomi, Pendapatan Asli Daerah, Dana Perimbangan Dan Sisa Lebih Pembiayaan Anggaran Terhadap Alokasi Belanja Modal Kabupaten/Kota SeBali. KRISNA: Kumpulan Riset Akuntansi, 9(1), 15-29.

Sari, D. M. M. Y., \& Wirama, D. G. (2018). Pengaruh PAD, DAU dan DAK pada Alokasi Belanja Modal dengan Pendapatan Per Kapita Sebagai Pemoderasi. E-Jurnal Akuntansi, 22(3), 2065-2087.

Sekaran, U., \& Bougie, R. (2013). Metode Penelitian untuk Bisnis Pendekatan Pengembangan Keahlian. Jakarta: Salemba Empat. 
Sholikhah, I., \& Wahyudin, A. (2014). Analisis belanja modal pada pemerintah kabupaten/kota di Jawa. Accounting Analysis Journal, 3(4).

Sugiyono. (2012). Metode Penelitian Bisnis. Bandung: Alfabeta.

Sugiyono. (2012). Metode Penelitian Kuantitatif Kualitatifdan R\&D. Bandung: Alfabeta.

Undang-Undang, R. I. (2004). Nomor 32 Tahun 2004. Tentang Pemerintah Daerah. Jakarta.

Undang-Undang, R. I. (2010). Nomor 28 Tahun 2009. Tentang Pajak Daerah dan Retribusi Daerah.

Wandira, A. G. (2013). Pengaruh PAD, DAU, DAK, dan DBH terhadap pengalokasian belanja modal. Accounting Analysis Journal, 2(1).

Waskito, W., Zuhrotun, Z., \& Rusherlisyani, R. (2019). Pengaruh Pertumbuhan Ekonomi, Pendapatan Asli Daerah, Dana Alokasi Umum, Dana Alokasi Khusus, dan Dana Bagi Hasil Terhadap Belanja Modal (Studi pada Pemerintah Kabupaten \& Pemerintah Kota di Provinsi Aceh). Reviu Akuntansi dan Bisnis Indonesia, 3(2), 220-238.

Yana, W. (2018). Pengaruh PAD, DAU, DBH, dan DOK Terhadap Belanja Modal Dengan SILPA sebagai Variabel Pemoderasi Pada Pemerintah Kabupaten/Kota di Provinsi Aceh.

Yovita, F. M., \& Utomo, D. C. (2011). Pengaruh Pertumbuhan Ekonomi, Pendapatan Asli Daerah, Dan Dana Alokasi Umum Terhadap Pengalokasian Anggaran Belanja Modal (Studi Empiris Pada Pemerintah Provinsi Se Indonesia Periode 20082010) (Doctoral dissertation, Universitas Diponegoro). 